\title{
Monika Janowicz
}

Szkoła Główna Gospodarstwa Wiejskiego w Warszawie

e-mail: monika_janowicz@sggw.pl

\section{REKOMENDACJA KSIĄŻKI \\ PT. INŻYNIERIA PROCESOWA \\ I APARATURA PRZEMYSEU SPOŻYWCZEGO \\ POD REDAKCJĄ NAUKOWĄ PIOTRA P. LEWICKIEGO}

DOI: $10.15611 /$ nit.2018.2.05

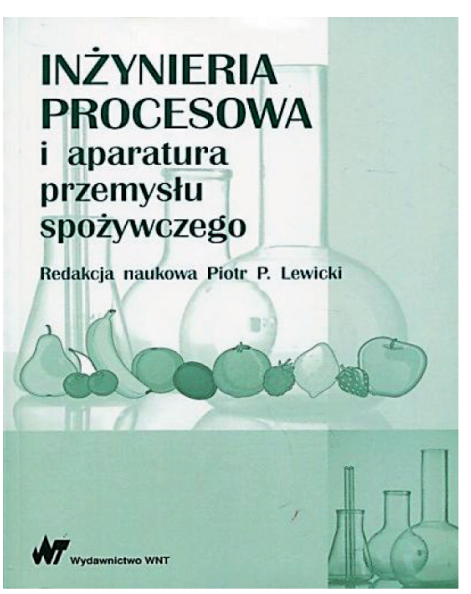

Rekomendowana publikacja pt. Inżynieria procesowa i aparatura przemystu spożywczego jest pierwszym w roku 2017 dodrukiem czwartego wydania książki powstałej pod redakcją naukową prof. dr. hab. Piotra P. Lewickiego, będącego również autorem rozdziałów $1-3 ; 5 ; 6 ; 8 ; 9 ; 13 ; 15 ; 16$; 20. Współautorami kwestii omawianych w książce są prof. dr hab. Andrzej Lenart, autor rozdziałów $4 ; 7 ; 10 ; 17 ; 18$, dr hab. inż. Roman Kowalczyk, prof. SGGW w Warszawie, autor rozdziałów 11; 12; 19 oraz dr hab. inż. Zbigniew Pałacha, prof. SGGW w Warszawie, autor rozdziału 14. Treści zawarte w rekomendowanym dziele dotyczą zagadnień inżynierii żywności i przedstawiają w sposób bardzo przejrzysty i prosty schematy, a także zasady działania urządzeń oraz linii technologicznych wykorzystywanych w przemyśle spożywczym. Atutem rekomendowanej pozycji jest przedstawienie w poszczególnych rozdziałach rozważań teoretycznych związanych z matematycznym i fizycznym opisem omawianych zagadnień. Taka forma prezentacji zjawisk zachodzących podczas procesów jednostkowych w ramach całości zabiegów technologicznych wykorzystywanych w przemyśle spożywczym wprowadza czytelnika w zagadnienia szczegółowe, jasno prezentując przebieg zmian zachodzących w obszarze procesów mechanicznych. Jednocześnie proste schematy przedstawiające zasadę działania stosowanych urządzeń są niewątpliwą zaletą niniejszej pozycji. Całość prezentowanych treści podzielono na cztery części.

W części pierwszej - Wprowadzeniu - przedstawiono definicje następujących pojęć: proces technologiczny, proces jednostkowy (często nazywany podstawowym), 
siła napędowa procesu, procesy przenoszenia pędu, energii i masy. Określono również, w jaki sposób opisywane są właściwości surowców lub półproduktów wykorzystywane w procesach zarówno technologicznych, jak i jednostkowych. Przedstawiono założenia transportu molekularnego, konwekcyjnego i promieniowania (dla energii cieplnej). Zwrócono także uwagę na przenoszenie energii mechanicznej, która w przemyśle spożywczym jest typowa dla procesów rozdrabniania, wytłaczania, formowania itp. Istotną kwestią omawianą we wprowadzającej części książki jest przedstawienie w bardzo przejrzysty i przystępny sposób zagadnień dotyczących bilansowania energii, pędu oraz masy odpowiednio za pomocą modelu mikroskopowego, warstewkowego, makroskopowego, oraz wyjaśnienie, w jaki sposób należy przygotowywać i projektować badania w skali laboratoryjnej, aby możliwe było ich przeniesienie do skali przemysłowej. Zagadnienia związane z powiększaniem skali przedstawione są z wykorzystaniem teorii podobieństwa, która pozwala na wyprowadzenie bezwymiarowych kryteriów podobieństwa mających określony sens fizyczny, stanowiących podstawę do uogólnienia charakterystyki procesu.

Część druga - Procesy mechaniczne - prezentuje w prosty i szczegółowy sposób zagadnienia związane z rozdrabnianiem ciał stałych, przesiewaniem i sortowaniem, przepływem płynów, formowaniem i ekstrudowaniem, ruchem ciał stałych i cieczy w płynach, fluidyzacją i transportem pneumatycznym, mechanicznym rozdzielaniem układów niejednorodnych, rozdrabnianiem cieczy, mieszaniem i aglomeracją. W zebranej w tej części książki wiedzy zawarto informacje dotyczące właściwości reologicznych materiałów wykorzystywanych w przemyśle spożywczym, które w zdecydowany sposób wpływają na przebieg omawianych procesów mechanicznych.

W części trzeciej autorzy prezentują zagadnienia związane z szeroko pojętym Przenoszeniem ciepła. W pierwszej kolejności wyjaśnione zostały zagadnienia związane z ruchem ciepła na drodze przewodzenia, konwekcji, promieniowania oraz złożonej wymiany ciepła, ze szczególnym uwzględnieniem wspomnianych już wcześniej bezwymiarowych kryteriów podobieństwa, stanowiących podstawę do uogólnienia charakterystyki procesów. Jednocześnie przedstawiono szczegółowo zagadnienia dotyczące nieustalonego ruchu ciepła, prezentując rozważania teoretyczne oraz przygotowując czytelnika do przejścia do dalszych rozważań nad ruchem ciepła w konkretnych zastosowaniach technologicznych, jak ogrzewanie, chłodzenie, odparowanie, zamrażanie zarówno surowców, półproduktów, jak i gotowych produktów.

W zagadnieniach dotyczących inżynierii procesowej zdecydowanie najtrudniejszą jej dziedzinę stanowią Procesy przenoszenia masy, które omówione zostały w czwartej części książki. Wstęp do tej części pracy wprowadza czytelnika w teoretyczne zagadnienia związane z ruchem masy. W prosty i przystępny sposób przedstawiono molekularny, konwekcyjny ruch masy oraz przenoszenie masy między fazami, uwzględniając kwestie związane z opisem zachodzących przemian za pomocą I i II prawa Ficka, modeli warstewkowych oraz penetracyjnych. Rozważania teoretyczne dla ułatwienia prezentowane są na prostych schematycznych rysunkach 
umożliwiających czytelnikowi wyobrażenie sobie zachodzących zjawisk. Całość wprowadzenia pozwala na zrozumienie zagadnień związanych z przebiegiem zmian zachodzących podczas ruchu masy w procesie suszenia, ekstrakcji, krystalizacji, rozpuszczania, destylacji i rektyfikacji oraz w procesach membranowych. Podobnie jak w poprzednich rozdziałach pracy również część czwarta jest bogata w liczne rysunki schematyczne prezentujące w sposób łatwy do zrozumienia zasadę działania opisywanych urządzeń.

Zagadnienia zebrane w książce pt. Inżynieria procesowa i aparatura przemysłu spożywczego pod redakcją naukową prof. dr. hab. Piotra P. Lewickiego są przedstawione w bardzo prosty i przejrzysty sposób, z wyjątkową znajomością zagadnień teoretycznych i praktycznych. Ponadto jest to jedyna publikacja w Polsce omawiająca w tak szeroki sposób problematykę inżynierii żywności i aparatury w przemyśle spożywczym. Interdyscyplinarny charakter niniejszego dzieła pozwala rekomendować tę publikację jako doskonałą dla osób studiujących na kierunkach związanych z dziedziną nauk rolniczych oraz inżynieryjno-technicznych, a także dla osób pracujących w przemyśle spożywczym. 